CASE REPORT

\title{
Congenital granular cell tumour of the newborn: A case report and literature review
}

\author{
David Steckler Jr MD, Larry A Sargent MD, Leslie A Turner MSN ACNP-BC
}

D Steckler Jr, LA Sargent, LA Turner. Congenital granular cell tumour of the newborn: A case report and literature review. Can J Plast Surg 2011;19(3):97-98.

A congenital granular cell tumour is rare, and presents in newborns as a mass arising from the alveolus. While its pathogenesis is unclear, it has no malignant potential and may, occasionally, spontaneously regress postpartum. Successful treatment usually consists of conservative simple excision.

Key Words: Congenital alveolar mass; Congenital epulis; Congenital granular cell tumour (CGCT)

\section{Une tumeur à cellules granuleuses congénitale du nouveau-né : un rapport de cas et une analyse bibliographique}

Il est rare d'observer une tumeur à cellules granuleuses congénitale. Elle se présente chez les nouveau-nés sous forme de masse qui émane de l'alvéole. On n'en connaît pas la pathogenèse, mais elle n'a pas de potentiel malin et peut parfois régresser spontanément postpartum. En général, le traitement consiste à procéder à une excision classique simple.
Congenital granular cell tumour (CGCT), also known as congenital epulis, is a rare tumour that originates from the dental alveolar mucosa. Typically, it presents as a mass protruding from the newborn's mouth. Its pathogenesis is not clear; however, it is always benign and never grows postpartum. The tumour can cause feeding or respiratory problems due to its location and size $(1,2)$. We report a case of a large congenital epulis and its management, followed by a brief literature review.

\section{HISTORY AND CLINICAL COURSE}

In July 2005, the plastic surgery service was consulted to evaluate a newborn with a large mass protruding from the mouth. The mass had been identified on prenatal ultrasound at 33 weeks' gestation by the high-risk obstetrics department (Figure 1). The child was born at term, and physical examination demonstrated a healthy infant with a $4 \mathrm{~cm} \times$ $3 \mathrm{~cm} \times 2 \mathrm{~cm}$ mass, and a second mass measuring $1 \mathrm{~cm} \times 1 \mathrm{~cm}$; both arose from the maxillary gingiva (Figures $2 \mathrm{~A}$ and $2 \mathrm{~B}$ ). The masses were clinically diagnosed as a rare congenital epuli, and were surgically excised and the mucosa primarily closed. Histopathological findings confirmed the clinical diagnosis (Figures $3 \mathrm{~A}$ and $3 \mathrm{~B}$ ). The gingival mucosa healed without complications, resulting in a normal

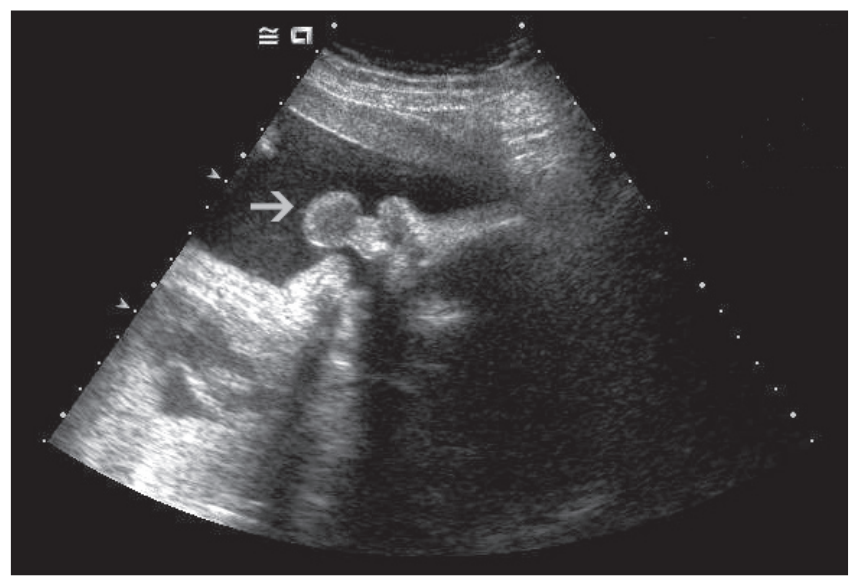

Figure 1) The congenital granular cell tumour in utero at 33 weeks' gestation. The stalk (arrow) can be seen

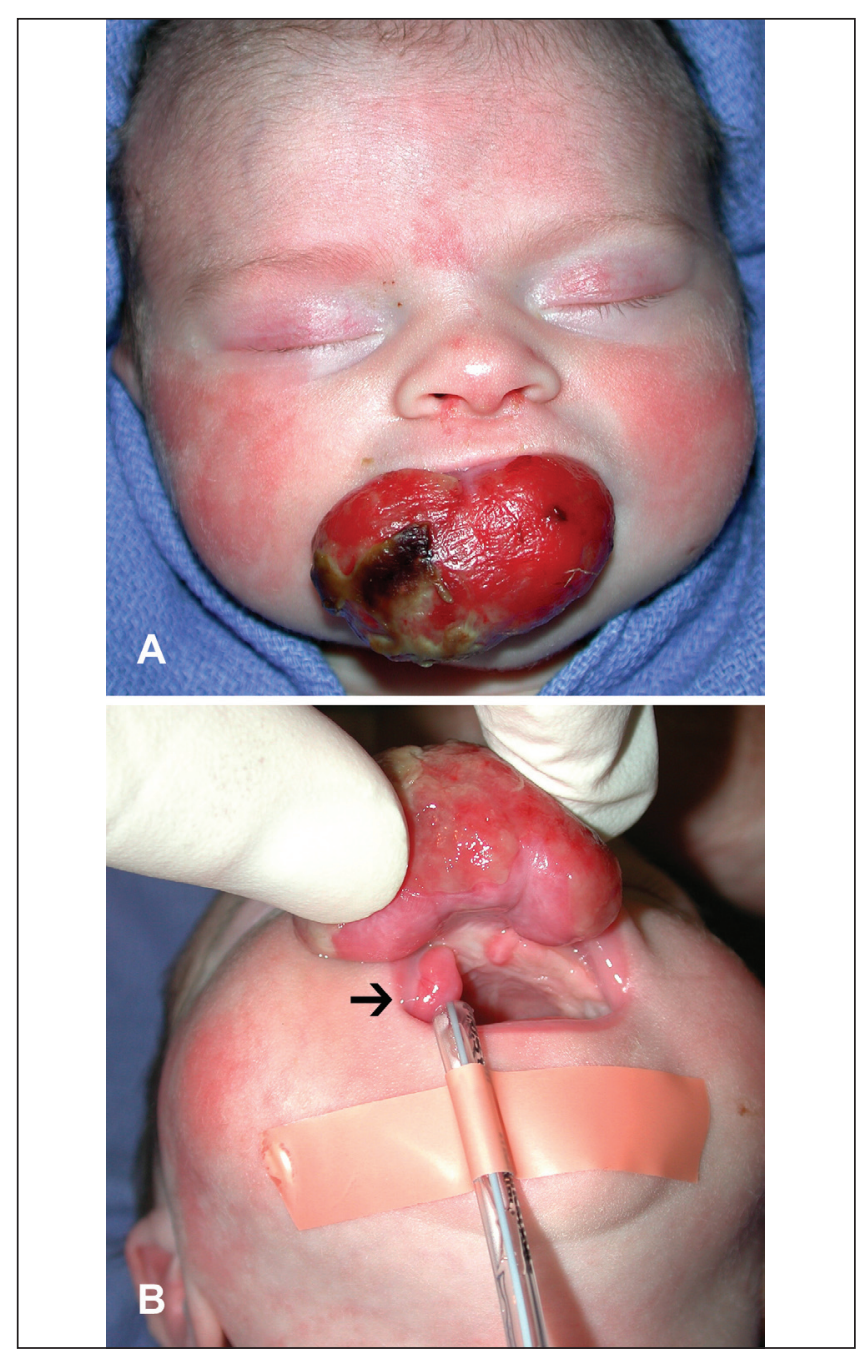

Figure 2) A The congenital granular cell tumour obstructing the mouth. B A second lesion (arrow) can be seen near the base of the larger one

Department of Plastic and Reconstructive Surgery, University of Tennessee College of Medicine Chattanooga, Chattanooga, Tennessee, USA Correspondence and reprints: Dr Larry A Sargent or Stacey Blanks, Department of Plastic and Reconstructive Surgery, University of Tennessee College of Medicine Chattanooga, 979 East Third Street, Erlanger Medical Mall, Suite C 920, Chattanooga, Tennessee 37403, USA.

Telephone 423-756-7134, fax 423-763-4571, e-mail utplastics@thepsg.org 


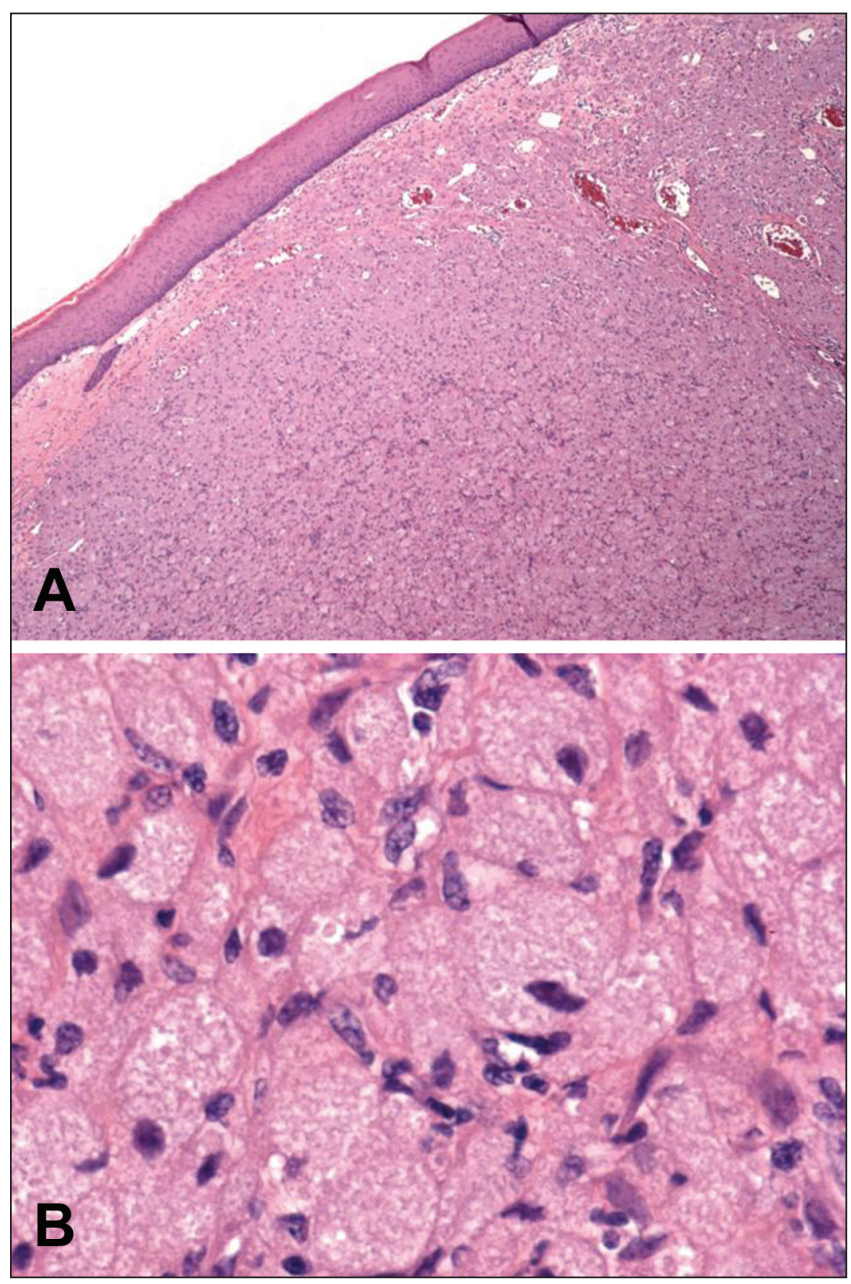

Figure 3) A Micrograph of the congenital granular cell tumour (original magnification $\times 4$ ) demonstrating the stratified squamous epithelium overlying the granular cell stroma and rich vascular supply. B Micrograph (original magnification $\times 60$ ) demonstrating the polygonal cells with eosinophilic granules. Hematoxylin and eosin stain was used

appearance (Figure 4). The child began orally feeding immediately and was discharged on the second postoperative day.

\section{BRIEF LITERATURE REVIEW}

CGCT or epulis is a benign tumour that is usually diagnosed clinically at birth or by prenatal ultrasound. Epulis - Greek for 'on the gum' was first reported by Neumann (3) in 1871. It is rare, and is reported fewer than 200 times in the English literature (1). The tumour presents as a fleshy, nonpulsatile, pedunculated lesion arising more frequently from the gingival mucosa of the maxilla than the mandible, at a ratio of $2: 1$ to $3: 1(4,5)$. It has a marked female preponderance, with a ratio of 9:1 (6). The lesions vary in size, from a few millimetres to as large as $9 \mathrm{~cm}(4)$.

The pathogenesis of the lesion is unclear. Speculation about its cellular origin include fibroblastic, histiocytic, myogenic, neurogenic, a reactive process or a hamartoma of mesenchymal cells $(1,4,5)$. On light microscopy, the lesion's histology resembles granular cell

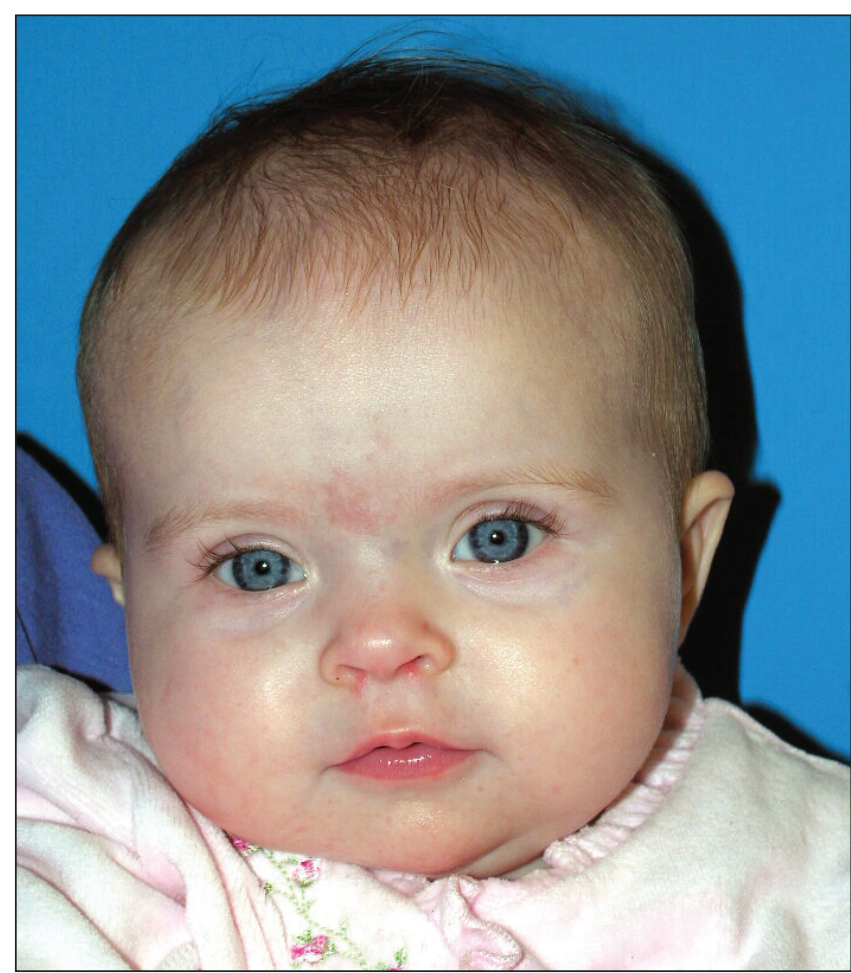

Figure 4) Postoperative result at six months of age

myoblastoma (6). Both CGCT and granular cell myoblastoma consist of polygonal cells containing cytoplasmic granules $(2,6)$. However, the two lesions demonstrate differences in immunohistochemical staining. Electron micrographs of CGCTs demonstrate cellular structures found in histiocytes and fibroblasts (6).

CGCT has no malignant potential. In fact, it ceases growing postpartum and has been reported to spontaneously regress $(2,5)$. Treatment usually consists of simple excision. Radical excision, which risks damage to developing tooth buds, should be avoided because the lesion has not been shown to recur $(2,5)$.

FINANCIAL SUPPORT: No financial support was provided by any external source or company.

\section{REFERENCES}

1. Nakata M, Annol K, Matsumore LT, et al. Prenatal diagnosis of congenital epulis: A case report. Ultrasound Obstet Gynecol 2002:20:627-9.

2. Drouelle P, Chassagne JF, Vignaud JM, et al. Obstructive congenital gingival granular cell tumor. Ann Otol Rhinol Laryngol 2003;112:388-91.

3. Neumann E. Ein von congenital epulis. Arch Heilkd $1871 ; 12: 189-90$.

4. Chami RG, Wang HS. Large congenital epulis of newborn. J Pediatr Surg 1986;21:929-30.

5. Loyola AM, Gatti AF, Pinto DS, et al. Alveolar and extra-alveolar granular cell lesions of the newborn: Report of case and review of literature. Oral Surg Oral Med Oral Pathol Oral Radiol Endod 1977;84:668-71.

6. Lack EE, Perez-Atayde AR, McGill TJ, et al. Gingival granular cell tumor of the newborn (congenital epulis): Ultrastructural observations relating to histiogenesis. Hum Pathol 1982;13:686-89. 